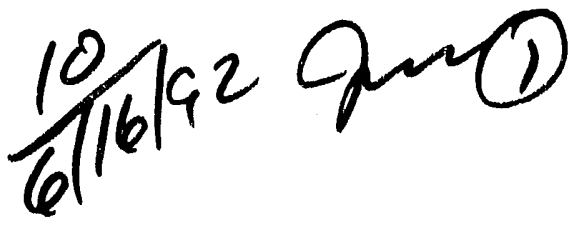

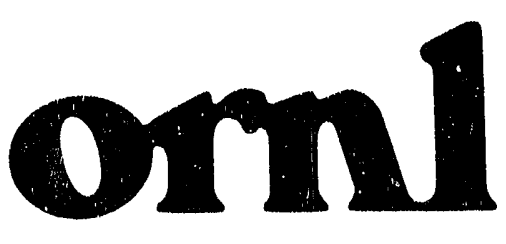

ORNL/TM-11940

OAK RIDGE

NATIONAL

LABORATORY

maprow makdetria
An Economic Analysis of Recordable Injuries at Martin Marietta Energy Systems, Inc.

E. K. Johnson

MANAGED BY

MARTIN MARIETTA ENERGY SYSTEMS, INC.

FOR THE UNITED STATES

DEPARTMENT OF ENERGY 
This report has been reproduced directly from the best available copy.

Avallable to DOE and DOE contractors from the Office of Scientific and Technical Information, P.O. Box 62, Oak Ridge, TN 37831; prices avallable from (615) 576-8401, FTS 626-8401.

Available to the public from the National Technical Information Service, U.S. Department of Commerce, 5285 Port Royal Rd., Springfield, VA 22161.

This report was prepared as an account of work sponsored by an agency of the United States Government. Neither the United States Government nor any agency thereof, nor any of their employees, makes any warranty, express or implied, or assumes any legal llability or responsibility for the accuracy, completeness, or usefulness of any information, apparatus, proauct, or process disclosed, or represents that its use would not infringe privately owned rights. Reference herein to any specific commerclal product, process, or service by trade name, trademark, manufacturer, or otherwise, does not necessarily constltute or imply its endorsement, recommendation, or favoring by the United States Government or any agency thereof. The views and opinions of authors expressed hereir do not necessarily state or reflect those of the United States Government or any agency thereot. 
Chemical Technology Division

AN ECONOMIC ANALYSIS OF RECORDABLE INJURIES AT

MARTIN MARIETTA ENERGY SYSTEMS, INC.

\author{
E. K. Johnson
}

This report was prepared as a special project in partial fulfillment of a Master of Science degree in Safety at The University of Tennessee

March 1992

Prepared by the

OAK RIDGE NATIONAL LABORATORY

Oak Ridge, Tennessee 37831-6285 managed by

MARTIN MARIETTA ENFRGY SYSTEMS, INC.

for the

U.S. DEPARTMENT OF ENERGY under coisract DE-AC05-84OR21400 


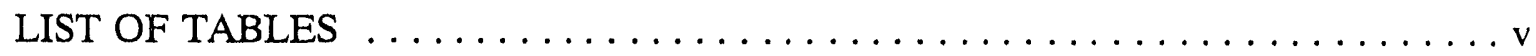

LIST OF FIGURES $\ldots \ldots \ldots \ldots \ldots \ldots \ldots \ldots \ldots \ldots \ldots \ldots \ldots$

DEFINITIONS AND ACRONYMS $\ldots \ldots \ldots \ldots \ldots \ldots \ldots \ldots \ldots$

ABSTRACT $\ldots \ldots \ldots \ldots \ldots \ldots \ldots \ldots \ldots \ldots \ldots \ldots \ldots \ldots \ldots \ldots \ldots \ldots \ldots \ldots$

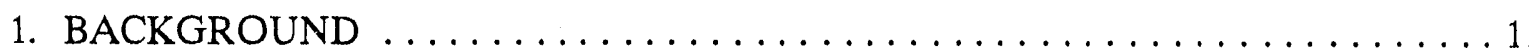

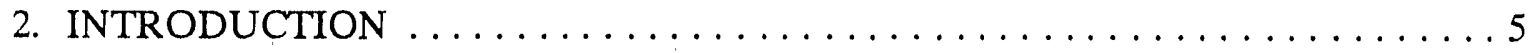

3. REVIEW OF RELATED LITERATURE $\ldots \ldots \ldots \ldots \ldots \ldots \ldots \ldots \ldots$

3.1 SOURCES OF INJURY STATISTICS $\ldots \ldots \ldots \ldots \ldots \ldots \ldots \ldots \ldots$

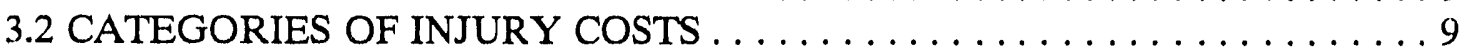

3.3 SURVEY OF RESEARCH STUDIES ON INJURY COSTS $\ldots \ldots \ldots \ldots \ldots$

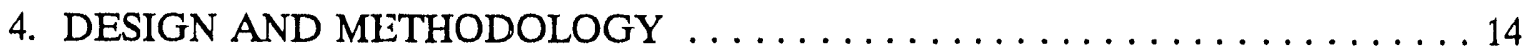

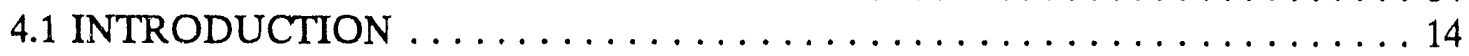

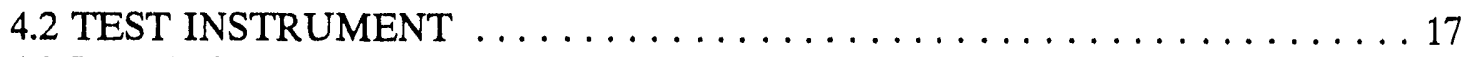

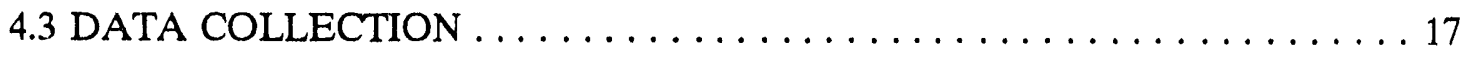

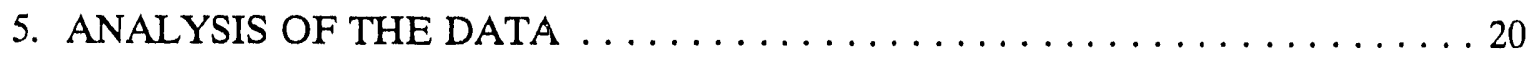

6. DISCUSSION AND CONCLUSIONS $\ldots \ldots \ldots \ldots \ldots \ldots \ldots \ldots \ldots \ldots \ldots$

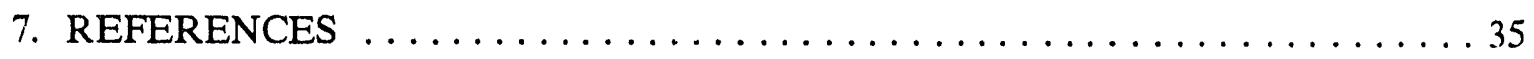

APPENDIX A. INVESTIGATOR'S COST DATA SHEET FOR

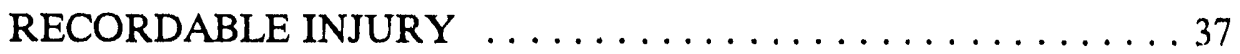

APPENDIX B. ACCIDENT INVESTIGATION REPORT $\ldots \ldots \ldots \ldots \ldots \ldots \ldots$ 


\section{LIST OF TABLES}

Table

Page

1. Recordable injuries for Martin Marietta Energy Systems, Inc., by calendar year . . 6

2. Energy Systems occupational injury and illness rate experience, by calendar

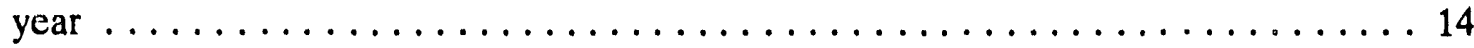

3. Energy Systems employment, by payroll designation $\ldots \ldots \ldots \ldots \ldots \ldots \ldots$

4. Summary of total injuries and questionnaire response rate, by plant site, for the period April-September 1986

5. Summary of injury costs for Energy Systems, by category $\ldots \ldots \ldots \ldots \ldots \ldots$

6. Time required for action of Accident Investigation Committee, by plant site $\ldots \ldots 23$

7. Summary of injury cost categories, by plant site, for the period April-September 1986

8. Summary of injury costs, by payroll classification, for the period April-September 1986

9. Weighted-average number of trips to the Medical Department per injury $\ldots \ldots \ldots 26$

10. Total injury cost, by plant site, for the period April-September 1986

11. Total injury cost, by payroll classification, for the period April-September 1986

12. Comparison of average costs for lost-workday cases and recordable-injury cases for the period April-September 1986

13. Comparison of the average costs of nonoccupational and occupational injuries, in constant dollars 


\section{LIST OF FIGURES}

Figure

Page

1. Distribution of Accident Investigation Committee sizes for the period AprilSeptember 1986

2. Distribution of injury cost (dollars per injury) for the period AprilSeptember 1986

3. Breakdown of the average injury cost, by category, for the period AprilSeptember 1986

4. Comparison of LWC and RI average costs, by category, for the period AprilSeptember 1986 


\section{DEFINITIONS AND ACRONYMS}

Accident - An unplanned, and sometimes injurious or damaging, event that interrupts the normal progress of an activity and is invariably preceded by an unsafe act or an unsafe condition, or possibly some combination thereof.

Accident Investigation Report - A document in which the formal, detailed description regarding an accident is summarized and submitted to the Accident Investigation Committee members, the Central Safety and Health Committee, Benefit Plans, and others, as appropriate.

Direct Cost - The monetary losses directly ensuing from an accident.

Incident Rate [Recordable Injury and Illness Rate (RIIR)] - The total number of incidents multiplied by $200,000 \mathrm{~h}$ and divided by the total number of employee-hours worked during the time period.

Indirect Cost - Any expense that is not directly associated with an accident occurrence but is real and measurable and would not have been incurred under normal circumstances.

Lost-Workday Case - Any recordable case that results in lost workdays. Days away from work are considered to be those workdays (consecutive or not) on which the employee should have worked but was absent because of an occupational injury or illness.

Recordable Illness - Any abnormal condition or disorder, except an occupational injury, that is caused by exposure to environmental factors associated with employment. It includes acute and chronic illness or diseases that may be caused by inhalation, absorption, ingestion, or direct contact of harmful substances.

Recordable Injury - An occupational death, regardless of the time between injury and death or the length of the illness, or an occupational injury (such as a cut, fracture, sprain, or amputation) that results from a work accident or from an exposure involving a single 
incident in the work environment. The injury will be recordable when it involves one or more of the following: (1) loss of consciousness, (2) restriction of work or motion, (3) transfer to another job, or (4) medical treatment other than first aid. Medical treatment other than first aid includes treatment that is administered by a physician or by registered professional personnel under the orders of a physician. 


\begin{abstract}
The William-Steiger Occupational Safety and Health Act (OSHA) was passed by the Congress and signed by the President of the United States in 1970. This law required all companies with more than 25 employees to maintain detailed information about each recordable injury, which is defined as any occupational illness or any work-related injury requiring more extensive treatment than first aid. However, compliance with OSHA standards did not require employers to keep records regarding the costs of recordable injuries or illnesses. The purpose of this study was to evaluate actual recordable U.S. Department of Energy injuries (as defined by OSHA standards) at a multi-plant corporation during a sixmonth period to determine the average costs of such injuries on the basis of site and payroll classification.
\end{abstract}

Approval for the study was obtained from Energy Systems, and a test instrument (based on the Simonds method of cost analysis) to collect the detailed elements of cost was designed, reviewed, and approved. The immediate supervisor of each injured employee was asked to complete the cost data sheet for each injury. Eighty-six percent of the questionnaires were returned and analyzed. There were two major accident categories of the 57 recordable injuries included in this study. Three were lost-workday cases; the remaining 54 were recordable injuries that required medical treatment other than first aid. The total cost of all 57 recordable injuries at the four plant sites was $\$ 108,663$. The average costs per injury for the sites were $\$ 1342$ for the Oak Ridge Gaseous Diffusion Plant (ORGDP), $\$ 1782$ for the Y-12 Plant, \$2822 for the Oak Ridge National Laboratory, and \$2.360 for the Paducah Gaseous Diffusion Plant. The average cost for all Energy Systems injuries was \$1906. The following variation was observed in the average cost per injury among the three employee payroll classifications: monthly, \$1728; weekly, \$2030; and hourly, \$1927. The average 
nonoccupational disabling-injury cost rate for ORGDP was consistently greater than the average recordable injury cost rate for Energy Systems. However, each case showed a similar pattern with regard to ranking of the average cost per injury among the payroll classifications. The average cost per injury declined in the following order: weekly, hourly, and monthly.

The conclusions were that the average cost of an injury ranged from $\$ 1340$ to $\$ 2360$ and the average cost of an injury is variable, depending on the plant site and the payroll designation. 


\title{
AN ECONOMIC ANALYSIS OF RECORDABLE INJURIES \\ AT MARTIN MARIETTA ENERGY SYSTEMS, INC.
}

\author{
E. K. Johnson
}

\section{BACKGROUND}

In 1970, the William-Steiger Occupational Safety and Health Act (OSHA) was passed by the Congress and signed by the President of the United States. Although several other job safety and health regulations existed prior to 1970, they were widely regarded as inadequate.

In the late 1800 s, several laws were passed governing coal wine safety. The Public Health Service's Office of Industrial Hygiene and Sanitation was created in 1914. Federal employees were covered by Workmen's Compensation Insurance as early as 1916 . The Walsh-Healey Act, which required government contractors to comply with safety and health standards, was passed in 1936. By the late 1930s and early 1940s, however, legislation relative to state worker's compensation and federal job safety had slowed markedly in this country.

A new trend began to develop with the onset of World War II - women entered the job force which had previously been dominated by male workers. As the number of women involved in industrial activities increased, health and safety concerns began to take on a new character. In addition, the steady increases in the educational and wage levels of the American work force in the late 1950s appeared to bring about a change in priorities and values. By comparison, job safety and health concerns became more important than the paycheck issue.

A wave of environmentalism began to emerge in the late 1960 s and fostered a climate receptive to the solution of occupational safety and health problems. At the time of deliberation over OSHA, approximately $65 \%$ of all collective bargaining agreements contained 
some provisions for health and safety. Possibly the single most important factor behind the passage of OSHA was the sharp increase in occupational injuries between 1961 and 1970. The reported injury rate in industry increased nearly $29 \%$ during this period, with 14,000 deaths being attributed to accidents on the job.'

OSHA, which was thought to be one of the most controversial pieces of legislation passed in recent history, was severely criticized by economists. "The most common criticism of OSHA was that it was too costly". ${ }^{2}$ The major expenses were the cost of compliance and the loss of productivity. The cost of compliance caused some companies to reject new product ventures; in other cases, companies were forced to close. Although the cost of compliance couid be calculated, the loss of productivity was difficult to quantify. The value of the benefits derived from a safer working environment was even more difficult to establish. Weidenbaum listed seven benefits that could be expected to result from the regulation of health and safety: ${ }^{3}$

1. productivity gains from those who would have otherwise been injured or ill,

2. greater enjoyment of life by those persons,

3. reduced costs of treatment and rehabilitation,

4. reduced costs of administering Workmen's Compensation Insurance and training replacements,

5. reduced need for private-sector efforts to encourage job safety and health,

6. reduced damages to plants and equipment, and

7. reduced disruption of work.

The National Safety Council estimated that the 1986 annual cost resulting from injuries and death, plus losses in motor vehicle mishaps and fires, was over $\$ 118$ billion. Most experts believed that this figure was too low for all injuries, even though it had more than tripled in the past 10 years. Moreover, the estimate was probably understated because 
it did not take into account indirect costs such as property damage, wages paid for nonproductive hours of the injured worker, cost of overtime necessitated by the injury, cost of wages paid for supervisory time spent on activities necessitated by the injury, cost of wages resulting from decreased output of the injured worker after his/her return to work, cost of the learning period for a new worker, uninsured medical cost borne by the company, cost of time spent by higher supervision and by clerical workers, and other miscellaneous costs (e.g., loss of profit on contracts canceled or orders lost, cost of excess spoilage of product by new employees, public liability claims, or cost of renting replacement equipment).

OSHA requires all companies with more than 25 employees to comply with standards that include keeping specific information with regard to recordable cases. A recordable case is defined as any occupational illness or atıy work-related injury case requiring more extensive treatment than first aid."

OSHA standards do not require employers to keep records regarding the cost of injuries or occupational illnesses, but do require rather detailed record keeping such as the following: (1) date of the injury or onset of illness, (2) employee's name, (3) employee's regular job title, (4) department in which the ernployee is regularly assigned, (5) brief description of the injury or illness, (6) date of injury-related death, (7) number of days away from work due to injury, (8) number of days of restricted work activity due to injury, (9) number of injuries without lost workdays, (10) type of illness (occupational skin disease or

\footnotetext{
Examples of recordable injuries include (1) death, regardless of the time between occupational injury or illness and death; (2) all occupational illnesses; and (3) all occupational injuries resulting in (a) lost workdays - either days away from work or days of restricted work activity, (b) medical treatment other than first aid, (c) loss of consciousness, (d) restriction of work or motion, (e) temporary or permanent transfer, or (f) termination of injured or ill employee.
} 
disorder, dust disease of the lungs, respiratory conditions due to toxic agents, poisoning, lungs, respiratory conditions due to toxic agents, poisoning, disorders due to physical agents, disorders associated with repeated trauma, and all other occupational illnesses), (11) date of illness-related death, (12) number of days away from work due to illness, (13) number of restricted workdays due to illness, and (14) number of illnesses without lost workdays. 


\section{INTRODUCTION}

In 1984, Martin Marietta Energy Systems, Inc., was selected as the contractor (succeeding Union Carbide Corporation) to manage three major DOE production and research facilities in Oak Ridge, Tennessee, and one production facility in Paducah, Kentucky. The facilities in Oak Ridge-all situated within the city limits but up to 10 miles from the residential areas-included the Oak Ridge National Laboratory (ORNL), the Oak Ridge Y-12 Plant, and the Oak Ridge Gaseous Diffusion Plant (ORGDP)." The Paducah Gaseous Diffusion Plant (PGDP) is located about 15 miles west of Paducah, Kentucky, along the Ohio River. At the time of the new contract, the comr ned employment for the four sites was more than 16,000 persons.

The two gaseous diffusion plants provided uranium enriched in the fissile ${ }^{235} \mathrm{U}$ isotope for use in nuclear power-generating facilities in the United States and foreign countries. Although the ORGDP had taken a lead role in the development of the gas centrifuge and atomic vapor laser isotope processes for advanced uranium enrichr..znt, it was placed in a standby condition during December 1985 . The Y-12 Plant produces components for various nuclear weapons systems vital to national defense. This plant also provides fabrication and other support for several weapons-designed agencies. Its extensive capabilities are not only used to meet defense necds, but also to support nuclear and other energy programs in the national space efforts. ORNL, which is one of the world's largest and most diverse research and development centers, is engaged in programs covering almost all areas of science and technology. The Laboratory's primary mission is to attain abundant, economic, and environmentally acceptable sources of energy. ${ }^{6}$

\footnotetext{
"On October 16, 1990, this facility was renamed the Oak Ridge K-25 Site.
} 
The total recordable injuries for the four sites in 1:84, 1985, and 1986 are summarized in Table 1. The total numbers of cases for the three years are 125,130 , and 122 , respectively.

Table 1. Recordable injuries for Martin Marietta Energy Systems, Inc., by calendar year

\begin{tabular}{lccc}
\hline Site & 1984 & 1985 & 1986 \\
\hline ORGDP & 31 & 16 & 22 \\
ORNL & 27 & 11 & 18 \\
PGDP & 12 & 12 & 9 \\
Y-12 & 55 & 91 & 73 \\
Total & 125 & 130 & 122 \\
\hline
\end{tabular}

Source: Unpublished internal memorandum, I. G. Speas to J. A. Barker et al., February 4, 1987.

Since no statistical evaluation had ever been conducted to determine the actual cost of recordable injuries a the Energy Systems sites, the objective of this study was to perform an in-depth evaluation of the recordable U.S. Department of Energy (DOE) injury cases (as defined by OSHA standards) for a defined period and to determine the financial burden being imposed. Principal questions were as follows:

1. What cost figure accurately reflected the expenses incurred for recordable injuries at the four plant sites?

2. What was the average cost of an injury for each site?

3. How did the average cost per injury vary among the three employee payroll classifications?

For the purpose of this study, it was assumed that the questionnaire (see Appendix A) was a valid and reliable instrument for obtaining information and the individual complsting the questionnaire was the appropriate supervisor or had first-hand information about the incident. 
The investigation was based on the following limitations:

1. Some of the subjects to be surveyed were no longer employed by the company and were, therefore, unavailable to complete the questionnaire.

2. Death benefits were not incorporated into the economic analysis since no occupationrelated deaths occurred during the specified time period.

3. Workmen's Compensation payments were not incorporated into the cost analysis since they were considered to be confidential.

4. This study was limited to the total recordable injuries at the four plant sites during the last six months (April-September) of fiscal y 2 ar 1986. 


\section{REVIEW OF RELATED LITERATURE}

\subsection{SOURCES OF INJURY STATISTITS}

A review of the literature revealed that little research had been performed to evaluate the economic aspects of occupational safety. Although there are numerous sources available for obtaining statistics about the number, frequency, severity, and types of injuries, few reliable data are available concerning the costs of occupational injuries. The National Safety Council publishes Accident Facts on an annual basis. The National Center for Health Statistics conducts the National Health Survey. State agencies, such as the state departments of vital statistics, state safety councils, and highway departments, are also sources of information. The National Electronic Injury Surveillance System is a computerized system that coilects data from selected hospital emergency rooms. The National Highway Traffic Safety Administration has a traffic accident record program. Law enforcement agencies, including municipal, state, and county organizations, provides accident investigation information. Insurance comnanies, such as the Metropolitan Life Insurance Company, issue a monthly publication called Statistical Bu'letin, and the Bureau of Labor Statistics prints an Annual Survey of Occupational Injuries and Illnesses.

These documents typically deal with the number and frequency of injuries as opposed to the economic impact of injuries on industry. The small number of studies that have been made to assess injury costs by individual investigators are limited in scope to only a few types of industries or nonoccupational injuries, which might not be comparable with regard to other industrial firms or recordable injury costs. 


\subsection{CATEGORIES OF INJURY COSTS}

Authorities seemed to agree that two primary categories of costs are associated with injuries. ${ }^{8}$ These are the direct costs and the monetary losses directly ensuing from an injury occurrence (e.g., costs of Workmen's Compensation payments and medical expenses). Direct costs are sometimes used synonymously with insured or visible costs ${ }^{9}-$ a situation which is sometimes misleading in the literature. A typical example of an area where confusion could arise involved the loss-of-equipment category. Although equipment damaged or lost in an injury was visible and direct, it was not always insured.

The other type of cost is indirect, or an expense not directly associated with an injury occurrence, but is real and measurable and would be incurred only as a result of the injury (e.g., wages paid above compensation costs, cost of supervisor's injury investigation, lost time of other workers in stopping to assist the injured or to watch, cost of wages by decreased productivity of the injured worker after return to work, cost of the learning period of a new worker, uninsured medical cost borne by the company, cost of renting replacement equipment, cost of excess spoilage of product by new employees, or miscellaneous costs such as loss of profit on contracts canceled or orders lost). ${ }^{10}$ Again, the synonymous usage of terms such as "hidden" or "uninsured" for studies of indirect costs can be confusing.

\subsection{SURVEY OF RESEARCH STUDIES ON INJURY COSTS}

In 1976, a cost-benefit study was performed as a doctoral dissertation at Texas A\&M University. ${ }^{11}$ The purpose was to assess the occupational safety activities of 140 chemical, paper, and wood product manufacturing firms in the state of Texas. One aspect of the study was to obtain dollar costs associated with work injuries. Three specific manufacturing industries were selected for the study. The first was the chemical and allied products industry, which had a better-than-average safety performance as measured by the lost-time injury 
frequency rate. The second industry was representative of paper and allied products firms because safety performance was near the average for the manufacturing sector. The last industry selected was lumber and wood products because, over the years, its safety performance had been poorer than the average experience as measured by the same lost-time injury rates.

The direct costs of work injuries (primarily consisting of death benefits paid to survivors) were based on information provided by the Texas State Board of Insurance. Since none of the firms was able to provide information about indirect costs, the study followed procedures recommended by an earlier research effort and, hence, assumed that in each case the indirect costs were equal to the direct cost. ${ }^{12}$

Other safety authorities have indicated that considerably more weight should be given to the indirect costs of injuries. According to N. K. Walters, of the E. I. du Pont de Nemours and Company, whose 1980 safety performance earned the National Safety Council's Award of Honor for the thirty-fourth time, the "hidden or indirect costs exceed the direct cost many times". ${ }^{13}$ L. C. Smith, a retired Director of Training for the National Safety Council, has indicated that indirect costs are "like an iceberg," hidden below the surface, and may be as much as six or seven times the visible or direct costs. ${ }^{14}$

R. H. Simonds developed a method for estimating the cost of industrial injuries as a doctoral dissertation at Northwestern University in 1949. The study was one of the earliest attempts to quantify the cost of injuries in an industrial setting that included 31 private companies, a U.S. Navy shipyard, and 4 organizations operated by a state or the federal government. The following types of industries were represented in the Simonds study: a heavy manufacturing company, 3 chemical companies, a state highway department, an ore mining company, a manufacturer of heat and pressure control equipment for aircraft, a spark- 
plug manufacturer, a manufacturer of pumps, a manufacturer of grinding machines, a repair shop for a municipal transportation system, a manufacturer of leather products, two heavy construction companies, a coach and truck manufacturer, a valve manufacturing company, a producer of laundry appliances, a light and power company, a manufacturer of paper products, a state highway department, a furniture manufacturer, a state university, and a production unit of the U.S. Army. In some cases, the cost of only one injury was evaluated by the Simonds study. These organizations were located in more than 16 states, Mexico, and the District of Columbia. The samples were taken from populations that ranged from 165 to over $25,000 .^{15}$

The Simonds study was important for two reasons. First, the methodology for estimating costs if industrial accidents, injuries, and/or illnesses was later adopted by the National Safety Council as the recommended procedure on a national basis. Second, prior to the study, there had been no agreement as to what cost factors should be included in the expense associated with an industrial injury. ${ }^{16}$

At the request of the President's Conference on Occupational Safety, the "Simonds Method" was published by the U.S. Department of Labor in 1955. A discussion of this method for estimating the cost of injuries is given in the text by Grimaldi and Simonds, entitled Safety Management. It states that the list of potential costs for all injuries and accidents may vary from case to case; in general, however, there are ten valid elements of uninsured costs. They are the (1) cost of wages paid for working time lost by workers who were injured; (2) net cost required to repair, replace, or straighten up material or equipment that was damaged in an accident; (3) cost of wages paid for working time lost by injured workers, other than Workmen's Compensation payments; (4) extra cost due to overtime work necessitated by an accident; (5) cost of wages paid to supervisors for their time spent on 
activities necessitated by the injury; (6) cost of wages due to decreased output of an injured worker after return to work; (7) cost of the learning period of a new worker; (8) uninsured medical cost borne by the company; (9) cost of time spent by higher supervision and clerical workers on investigations or in the processing of compensation applications forms; and (10) miscellaneous unusual costs (e.g., cost of liability claims or of renting replacernent equipment). Grimaldi and Simonds suggest that if individual organizations desire to obtain specific information about their own firms, the procedures recommended by the National Safety Council should be followed. ${ }^{17}$

Another study conducted as a doctoral dissertation by Imre in 1976 replicated the Simonds study to support or refute the earlier findings by Simonds. The information for his project was obtained from two hospitals, two utilities, and three manufacturing companies. This study collected data from two types of organizations that Simonds had not reviewed: hospitals and utilities. The major finding was that the total average costs per case for the two findings were roughly comparable. ${ }^{18}$

The Simonds Method was also used by Blankenship to evaluate the costs of 66 nonoccupational disabling injuries at the ORGDP in $1979 .{ }^{19}$ The study was the first of its kind in that it dealt solely with off-the-job injuries. The study divided the various costs associated with injuries into two categories, insured and uninsured. The insured-cost categories included medical and death claims paid by the company and the associated administrative fees paid to insurance carriers. The uninsured-cost categories included (1) personal-leave time granted to a spouse; (2) any necessary overtime to compensate for lost productivity of the injured worker; (3) time paid for temporary workers to substitute for the injured worker; (4) supervisory time for instructing the transferred worker, and transferredworker productivity loss; (5) supervisory time, training time, and lost productivity associated 
with the assignment of a new worker not familiar with the job; (6) time spent by the supervisor, clerical staff, higher management, and safety staff for administrative responsibilities directly related to the injury: (7) noninjured worker productivity loss as a result of discussing the accident; (8) cost of the medical services provided by the company for follow-up treatment; and (9) any miscellaneous expenses. Although the study was limited to only one of the four plants, operated for the DOE at the time by the Union Carbidc Corporation, Nuclear Division, it resulted in an average-per-injury cost by payroll designation. Specifically, the average cost per injury (in 1979 dollars) by payroll designation was $\$ 3281$ for monthly, $\$ 6798$ for weekly, and $\$ 6449$ for hourly workers.

All three of these studies point out that (1) the usual industrial accounting methods do not separate and distinguish the direct costs incurred as a result of work injury; (2) the average cost of an injury is significant; and (3) the use of an average cost per injury can be estimated by previous findings, but the unique cost for a specific company can be obtained only by conducting a simulation. 


\section{DESIGN AND METHODOLOGY}

\subsection{INTRODUCTION}

The safety performance records for Energy Systems during 1984, 1985, and 1986 compared well with other organizations in the DOE complex. The Recordable Injury and Illness Rate (RIIR) experience, by site, is given in Table 2. In 1984 the highest RIIR, 1.00, was at the PGDP; and the lowest, 0.69, was at ORNL. In 1985 the Y-12 Plant had the highest rate, 1.22; and, again, the ORNL site had the lowest, 0.28 . Similarly in 1986, the 1985 pattern was repeated with the highest RIIR, 1.10, at Y-12 and the lowest, 0 46, at ORNL.

The overall OSHA recordable cases (per 100 full-time employees) experienced by the nation, as a whole, for 1984,1985 , and 1986 were $7.00,6.31$, and 7.00, respectively. ${ }^{21}$ The four sites had experienced a very favorable occupational safety record for many years. Each

Table 2 Energy Systems occupational injury and illness rate experience, by calendar year

\begin{tabular}{llll}
\hline Site & 1984 & 1985 & 1986 \\
\hline ORGDF & 0.83 & 0.51 & 0.95 \\
ORNL & 0.69 & 0.28 & 0.46 \\
PDGP & 1.00 & 1.02 & 0.82 \\
Y-12 & 0.77 & 1.22 & 1.10 \\
Total & 0.78 & 0.83 & 0.83 \\
\hline
\end{tabular}

'Total number of recordable injury cases per 200,000 employee-hours worked. 1987.

Source: Environmental Safety and Health Division,

year the company had received numerous national, DOE, and corporate safety awards. Even though the safety record was widely acclaimed, management had frequently inquired about 
the economic impact of recordable injuries but had never specifically collected or reviewed these costs. To obtain more specific information, a descriptive research investigation was designed to categorize and quantitatively evaluate the costs of recordable injuries. Grimaldi and Simonds recomirended that the period for study be only long enough to accumulate sufficient cases to establish reasonably reliable averages. ${ }^{22}$ A statistician was asked to evaluate the Energy Systems recordable injury experience for a five-year period (1981-1985) and to establish the upper and lower control limits with a $95 \%$ confidence interval. Assuming there were no drastic population changes in 1986 , it was determined that a reliable analysis could be conducted if the number of recordable injuries to be evaluated fell between 51 and 84 . The actual calendar-year recordable injury experience as of April 30, 1986, was 41, and the population (see Table 3) was 16,024. Therefore, a six-month evaluation period was considered a reasonable period of time to obtain a sufficient number of examples for this investigation.

The elements of cost selected for the evaluation were (1) cost of wages paid for working time lost by the injured worker (other than Workmen's Compensation payments) and decreased output upon return to work; (2) costs to repair, replace, or straighten up material, equipment, or the work area damaged in the injury; (3) cost of overtime necessitated by the injury; (4) r/sst of wages paid to supervision, clerical workers, or higher management on activities resulting from an injury; (5) cost of new-worker training or productivity lost; and (6) cost of uninsured medical expenses borne by the company. Copies of each of the "Accident Investigation Reports" (see Appendix B) for the 66 injuries experienced during this time period were analyzed. 


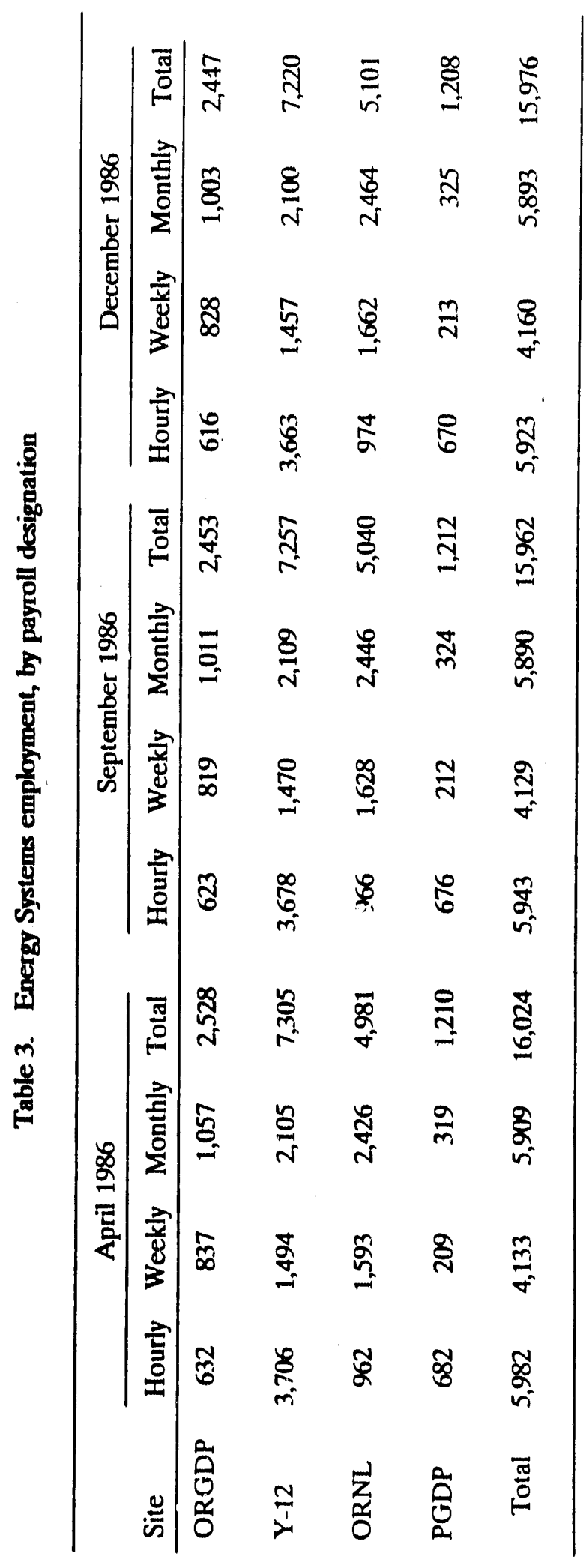




\subsection{TEST INSTRUMENT}

The test instrument ("Investigator's Cost Data Sheet for Recordable Injury") was developed by modifying the procedures advocated by Simonds and the National Safety Council for calculating the average cost of occupational injuries. ${ }^{17}$. As shown in Appendix A, the questionnaire, consisting of nine questions, was developed to obtain the necessary information associated with each injury. This questionnaire was reviewed by safety professionals from Energy Systems and The University of Tennessee.

\subsection{DATA COLLECTION}

Approval for this study was obtained from the Energy Systems Environmental and Safety Activities Organization (ESAO). The manager of the ESAO sent each of the plant site managers a letter announcing support for this survey and requesting their cooperation and assistance. The sample consisted of all recordable accidents at the Energy Systems sites during the last six months (April through September) of fiscal year 1986. There were a total of 66 subjects. A copy of the "Accident Investigation Report" (required by Energy Systems procedures) for each of the 66 recordable injuries was obtained. This document provided the basic information about the injury, including the name of the injured employee, incident classification, date and nature of the injury, supervisor of the injured employee, and plast-site designation.

Since the first-line supervisors were most familiar with the nature and extent of the injury, it was judged appropriate that they complete the questionnaire. Thus, the supervisor of each victim was sent a letter explaining the purpose of the study and asking him/her to complete and return the "Investigator's Cost Data Sheet for Recordable Injury" questionnaire. To encourage honest and candid responses, emphasis was placed on the assurance of 
confidentiality and on the overall objective, which was to determine the average cost of an injury - not to analyze performance levels of individuals or departments or to seek ways of handling injuries at a lower cost. Supervisors were encouraged to make rough estimates of cost and time when exact figures were not available.

Of the 66 questionnaires distributed, 57 were completed and returned; thus, the response rate was $86 \%$. Since participation in this study was not mandatory, it was not surprising that $14 \%$ of the test instruments were not returned. The total number of responses fell between the previously established control limits of 51 and 84 . When incomplete responses were received, contact was made with the supervisor for additional information.

The majority of the questions on the $t \epsilon_{*}$ ! instrument required calculations of estimates of employee time multiplied by a rate of pay. Because individual salary information is available only to an employee's line management, average base salary rates (by payroll classification: monthly, weekly, and hourly) per plant site were utilized. These rates were obtained from the Energy Systems' Wage and Salary Organization. In cases where it was considered appropriate, the site-specific fringe benefit and overhead rates were applied. These rates were obtained from the Central Accounting Organization.

The rate used for calculating the uninsured medical costs borne by the company was obtained from the Office of the Comptroller. Each year, Energy Systems (with DOE approval) establishes a uniform price standard for medical services to non-Energy Systems employees. Since the rate is based on actual experience, the occupational visit - emergency rate of $\$ 75$ - was utilized for the initial visit to the Medical Department by the injured employee. Each subsequent trip was based on the occupational visit - routine rate of $\$ 24$. If the initial treatment was administered at a local physician's office or hospital (due to the recommendation of the site medical staff or because the injury occurred on an off-shift), the emergency rate was assumed to be $\$ 225$ (three times the established $\$ 75$ rate). 
The safety departments at the various sites were contacted for an estimate of the time that their staff members, excluding the Accident Investigation Committee, spent on each injury.

Once data were collected and the sample finalized, results from the test instruments were summarized and calculations for each element of cost were completed. The mean cost was computed for each injury on the basis of plant site, payroll classification, and Energy Systems as a whole. Each category of cost was analyzed as a percentage of the total cost. 


\section{ANALYSIS OF THE DATA}

A review of the information provided on the Accident Investigation Reports revealed that a total of 66 injuries occurred during the period April-September 1986. Only three of these resulted in lost-workday cases. The lost-workday cases were at the Y-12, ORNL, and PGDP sites ( 3 lost days, 11 lost days, and 1 lost day, respectively). The remaining 63 injuries were categorized as recordable injuries. Consistent with the experience gained in previous years, the majority, or $62 \%$, of the total injuries occurred at the Y-12 Plant and the fewest number of injuries - 5, or $8 \%$ of the total - occurred at the PGDP site. A comparison of the injuries reported on the Accident Investigation Reports and the responses to the Investigator's Cost Data Sheet for Recordable Injury forms, by site, is presented in Table 4.

The data provided on the test instrument were summarized, and average costs by category, site, and payroll classification were computed. In Table $s$, the elements of cost associated with an injury were summarized into 11 categories. The first and predominant cost was the time spent by the Accident Investigation Committee, which represented $41 \%$ of the total. The committee size ranged from 2 to 9 people, with an average of 6 . The

Table 4. Summary of total injuries and questionnaire response rate, by plant site, for the period April-September 1986

\begin{tabular}{lcccc}
\hline Plant site & $\begin{array}{c}\text { Number } \\
\text { of } \\
\text { injuries }\end{array}$ & $\begin{array}{c}\text { Percent } \\
\text { of total }\end{array}$ & $\begin{array}{c}\text { Number of } \\
\text { respondents }\end{array}$ & $\begin{array}{c}\text { Percent } \\
\text { of total }\end{array}$ \\
\hline ORGDP & 12 & 18 & 7 & 58 \\
Y-12 & 41 & 62 & 38 & 93 \\
ORNL & 8 & 12 & 7 & 88 \\
PGDP & 5 & 8 & 5 & 100 \\
$\quad$ Total & 66 & 100 & 57 & 86 \\
\hline
\end{tabular}


Table 5. Summary of injury costs for Energy Systems, by category

\begin{tabular}{lrr}
\hline \multicolumn{1}{c}{ Category } & \multicolumn{2}{c}{ Cost } \\
\cline { 2 - 3 } & \multicolumn{1}{c}{$\$$} & $\%$ \\
\hline Accident Investigation Committee & 43,954 & 41 \\
Lost time of injured employee & 16,492 & 15 \\
Decreased productivity & 16,313 & 15 \\
Noninjured employee lost time & 3,700 & 3 \\
Replacement worker & 3,338 & 3 \\
Overtime & 890 & 1 \\
Time of supervisor & 5,430 & 5 \\
Time of clerical workers & 1,240 & 1 \\
Time of higher management & 5,247 & 5 \\
Time of Safety Department staff & 2,623 & 2 \\
Uninsured medical services & 9,436 & 9 \\
Total & 108,663 & 100 \\
\hline
\end{tabular}

${ }^{a}$ Excluding time spent on Accident Investigation Committee.

frequency distribution for the committee sizes is illustrated in Fig. 1. The total amount of time an investigation committee spent in meetings ranged from 1 to $17 \mathrm{~h}$, for a mean average of $4.4 \mathrm{~h}$. For all 57 injury investigations, the company paid for a total of $1319.75 \mathrm{~h}$ of staff time. A summary of total staff time, by plant site, is presented in Table 6. The second and third highest costs were associated with the lost time and the decreased productivity, respectively, of the injured employee; each of these costs represented $15 \%$ of the total. The fourth major component of cost was the uninsured medical services provided by the company, which accounted for $9 \%$ of the total. The cost of the time spent by supervisors, clerical 


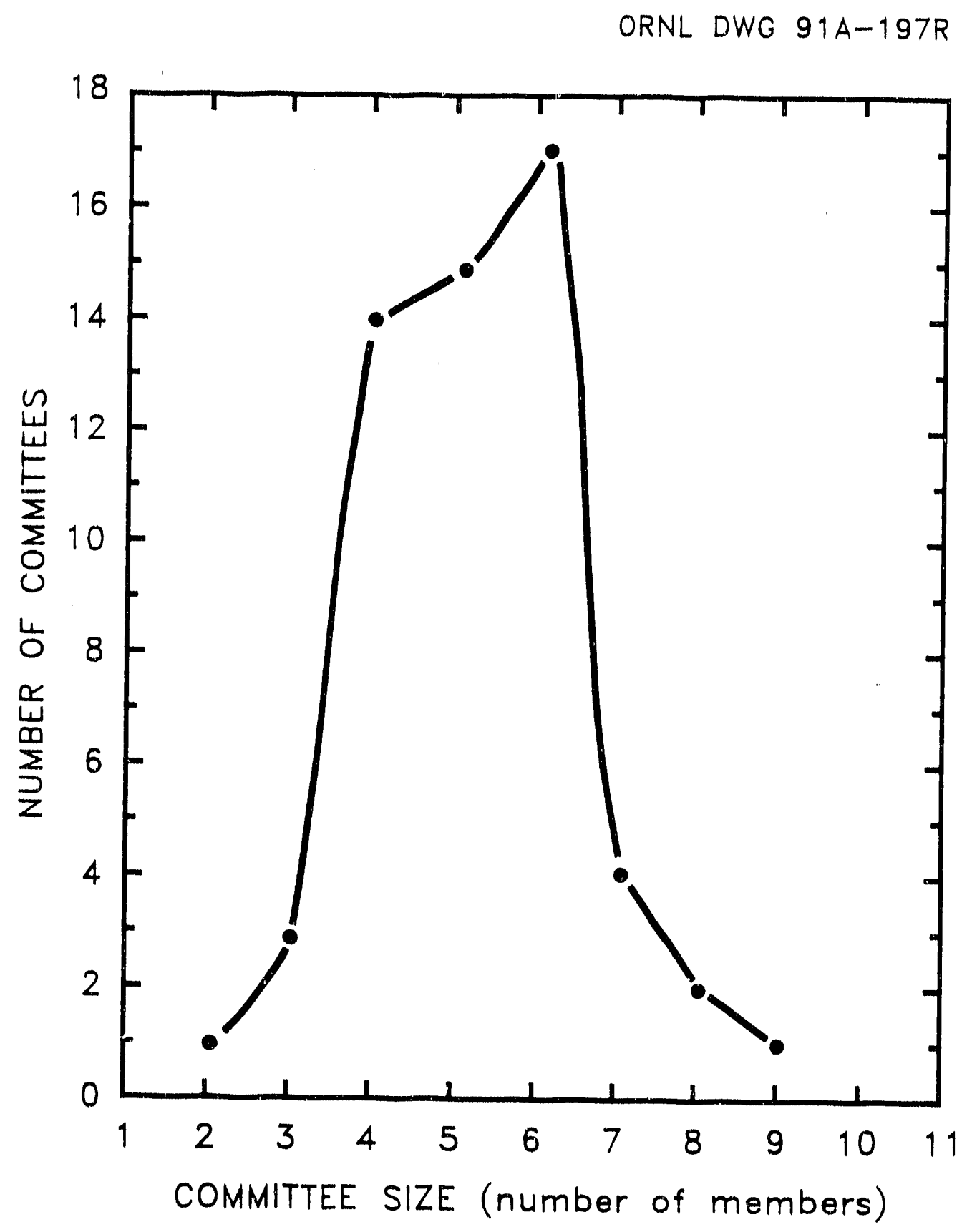
Fig. 1. Distribution of Accident Investigation Committee sizes for the period April-September
1986. 
Table 6. Time required for action of Accident Investigation Committee, by plant site

\begin{tabular}{lcccc}
\hline Site & $\begin{array}{c}\text { Time } \\
(\mathrm{h})\end{array}$ & $\begin{array}{c}\text { Percent } \\
\text { of total }\end{array}$ & $\begin{array}{c}\text { Number } \\
\text { of } \\
\text { injuries }\end{array}$ & $\begin{array}{c}\text { Average } \\
\text { staff time } \\
\text { per injury } \\
(\mathrm{h})\end{array}$ \\
\hline ORGDP & 170.75 & 13 & 7 & 24.4 \\
Y-12 & 803.50 & 61 & 38 & 21.1 \\
ORNL & 267.50 & 20 & 7 & 38.2 \\
PGDP & 78.00 & 6 & 5 & 15.6 \\
$\quad$ Total & $1,319.75$ & 100 & 57 & 23.2 \\
\hline
\end{tabular}

workers, and higher management in addressing the details associated with the injury totaled an additional $11 \%$, while the costs associated with the replacement worker and the lost time of noninjured employees were $3 \%$ each.

A comparison of the categories of cost, by plant site and by payroll classification, is presented in Tables 7 and 8, respectively. At each of the sites, the single most significant cost factor was the time required by the Accident Investigation Committee to resolve the details. The pattern of costs for each plant very closely paralleled the Energy Systems totals. One significant deviation was the cost of medic 11 services at the PGDP, which was attributed to the multiple trips to the Medical Department for treatment of an individual injury (see Table 9). One respondent indicated that the total number of such trips was 25 ; hence, the average number of trips to the Medical Department for the 5 injuries at the PGDP was greater than the average. 


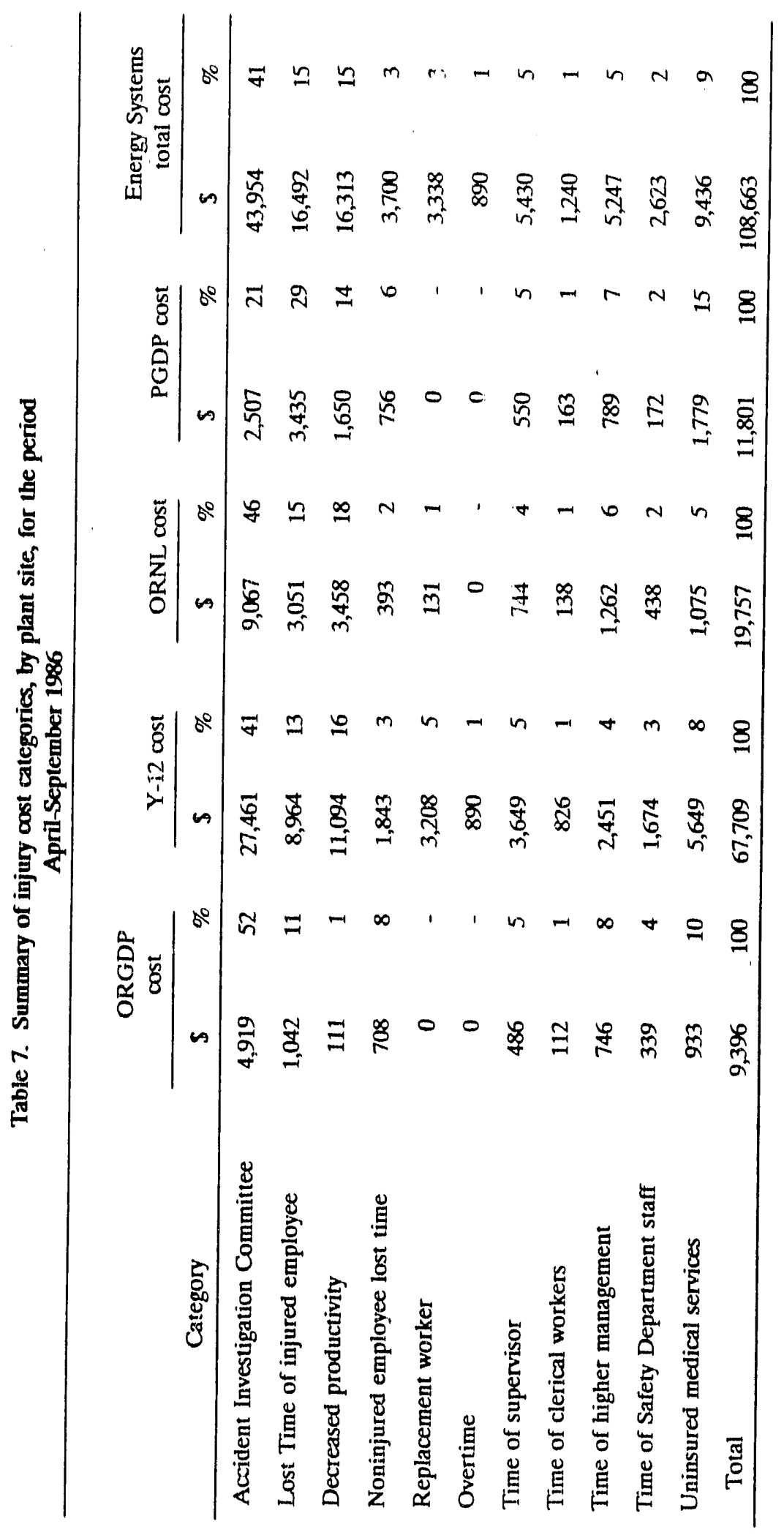




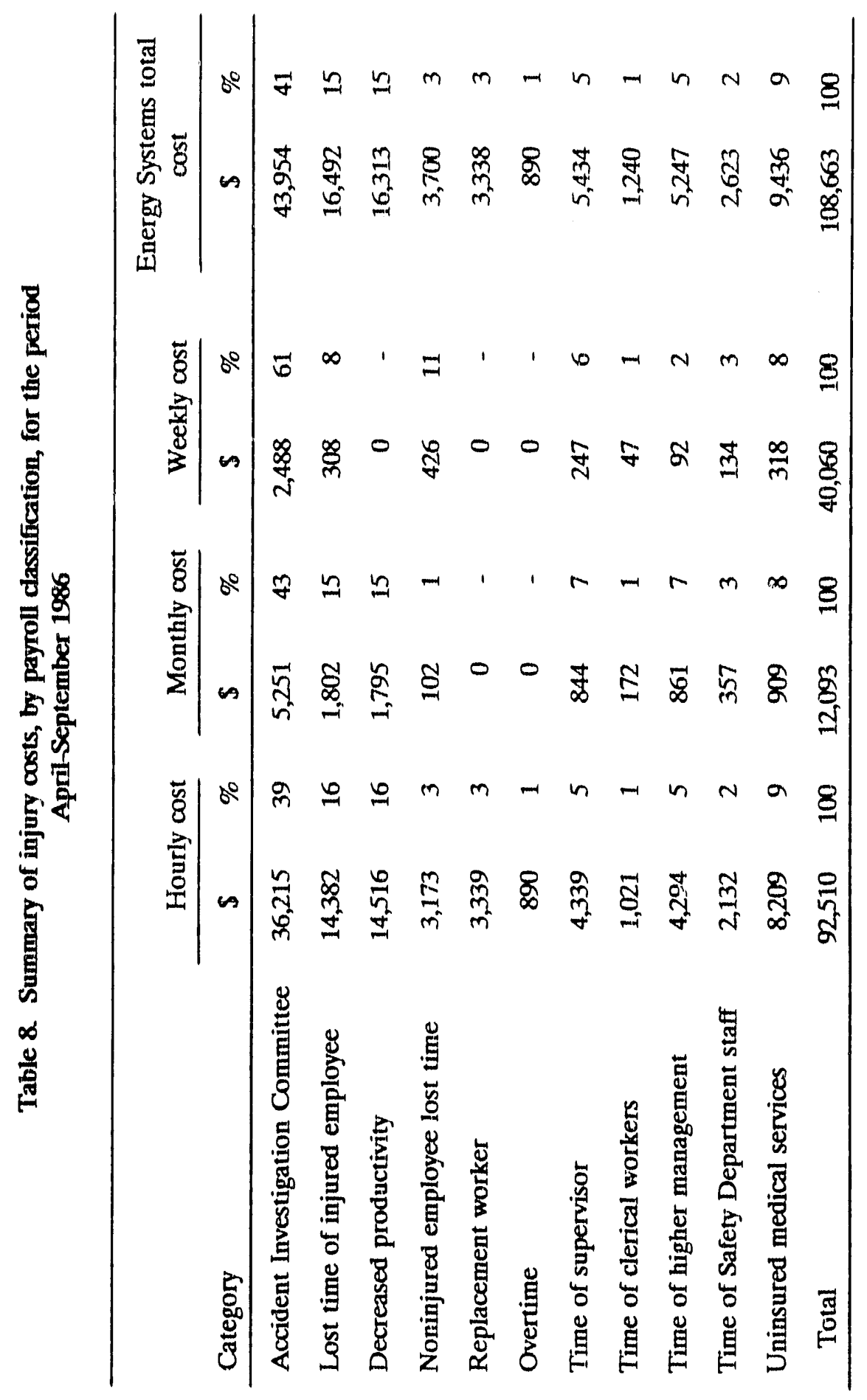


Table 9. Weighted-average number of trips to the Medical Department per injury

\begin{tabular}{lcc}
\hline Plant site & No. of injuries & $\begin{array}{c}\text { Average number of trips } \\
\text { per injury }\end{array}$ \\
\hline ORGDP & 7 & 3.4 \\
Y-12 & 38 & 3.0 \\
ORNL & 7 & 4.3 \\
PGDP & 5 & 10.0 \\
Energy Systems & 57 & 3.8 \\
\hline
\end{tabular}

The total cost (presented in Table 10) of the 57 injuries was $\$ 108,663$. The ORGDP site experienced $12 \%$ of the injuries, which accounted for $9 \%$ of the total cost. The Y-12 Plant had $67 \%$ of the total injuries, for $62 \%$ of the total cost. ORNL had $12 \%$ of the total injuries, for $18 \%$ of the cost, while the PGDP had only $9 \%$ of the total injury but experienced $11 \%$ of the total cost. ORNL had the highest average cost per injury at $\$ 2822$, while the ORGDP had the lowest average cost of $\$ 1342$.

While the total actual cost per injury ranged from $\$ 406$ to $\$ 8,207$, the typical injury cost is $\sim \$ 2,000$, as is shown in Fig. 2.

A breakdown of the cost, by payroll classification, is shown in Table 11. The comparison of the percentage of the total injuries to the total cost was more equitably represented when viewed from a payroll perspective. The number of injuries on the monthly payroll (12\%) amounted to $11 \%$ of the total cost. The number of injuries and the fraction of total cost attributed to personnel on the weekly payroll amounted to $4 \%$ each. The total number of injuries experienced by the hourly employees amounted to $85 \%$ of the total cost. The average costs per injury for the monthly, weekly, and hourly payroll classifications were $\$ 1728$, $\$ 2030$, and $\$ 1927$, respectively. The overall average cost per injury was $\$ 1906$. 
Table 10. Total injury cost, by plant site, for the period April-September 1986

\begin{tabular}{lcrrrrc}
\hline & \multicolumn{2}{c}{ Injuries } & & \multicolumn{2}{c}{ Cost } & \multicolumn{2}{c}{ Average cost/injury } \\
\cline { 2 - 3 } \cline { 6 - 7 } Site & Number & $\%$ & & $\$$ & $\%$ & $(\$)$ \\
\hline ORGDP & 7 & 12 & 9,396 & 9 & 1,342 \\
Y-12 & 38 & 67 & 67,709 & 62 & 1,782 \\
ORNL & 7 & 12 & 19,757 & 18 & 2,822 \\
PGDP & 5 & 9 & 11,801 & 11 & 2,360 \\
Total & 57 & 100 & 108,663 & 100 & 1,906 \\
\hline
\end{tabular}

Table 11. Total injury cost, by payroll classification, for the period April-September 1986

\begin{tabular}{lcrrrrr}
\hline & \multicolumn{2}{c}{ Injuries } & & \multicolumn{2}{c}{ Cost } & \multicolumn{2}{c}{ Average cost/injury } \\
\cline { 2 - 4 } \cline { 5 - 6 } Payroll & Number & $\%$ & & $\$$ & $\%$ & $(\$)$ \\
\hline Monthly & 7 & 12 & 12,093 & 11 & 1,728 \\
Weekly & 2 & 4 & 4,060 & 4 & 2,030 \\
Hourly & 48 & 84 & 93,510 & 85 & 1,927 \\
Total & 57 & 100 & 108,663 & 100 & 1,906 \\
\hline
\end{tabular}

The average cost of an injury, by category, is illustrated in Fig. 3. The largest fraction of the cost of an injury was attributed to the time spent by the Accident Investigation Committee (41\%), whereas the lost time and decreased productivity of the injured employee constituted the next largest fraction (30\%).

A comparison of the average cost of a lost-workday case (LWC) with that of a recordable injury (RI) is presented in Table 12. The average cost of an LWC accident was $\$ 2717$, or $42.5 \%$ higher than the average of all accidents $(\$ 1906)$ and $46 \%$ higher than the average RI accident rate at $\$ 1861$. 


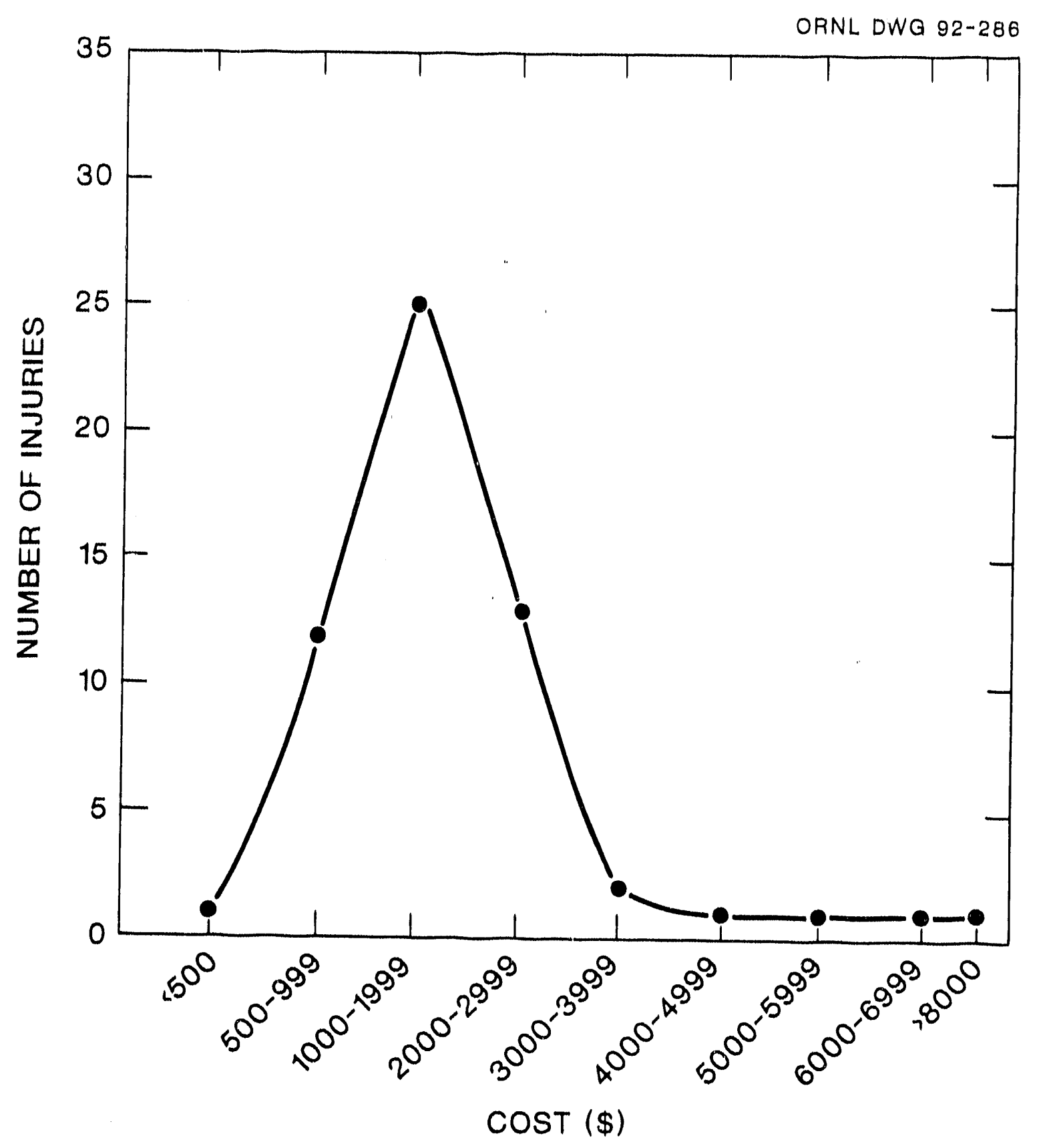

Fig. 2. Distribution of injury cost (dollars per injury) for the period April-September 1986. 


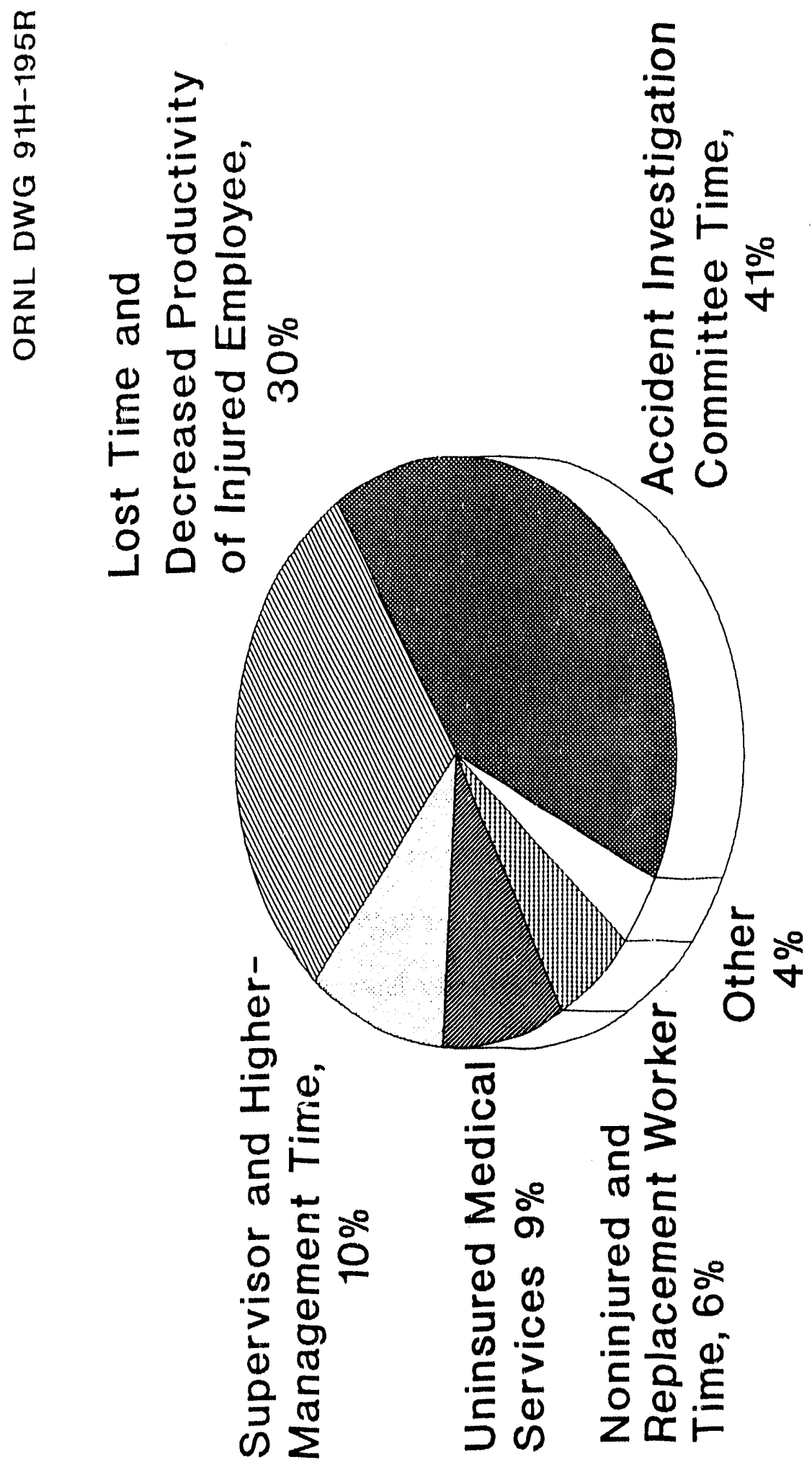


Table 12. Comparison of average costs for lost-workday cascs and recordable-injury cases for the period April-September 1986

\begin{tabular}{lccccc}
\hline & & \multicolumn{2}{c}{ Total cost } & \\
\cline { 4 - 5 } Type of injury & $\begin{array}{c}\text { Number of } \\
\text { injuries }\end{array}$ & $\begin{array}{c}\text { Percent } \\
\text { of total }\end{array}$ & \multicolumn{1}{c}{$\$$} & $\begin{array}{c}\% \text { of } \\
\text { total }\end{array}$ & $\begin{array}{c}\text { Average cost per } \\
\text { injury }(\$)\end{array}$ \\
\hline Lost-workday case & 3 & 5 & 8,151 & 8 & 2,717 \\
Recordable injury & 54 & 95 & 100,512 & 92 & 1,861 \\
Total & 57 & 100 & 108,663 & 100 & 1,906 \\
\hline
\end{tabular}

Figure 4 shows a comparison of the average LWC and RI costs, by category. Consistent with the Energy Systems average, the majority of the cost was attributed to the Accident Investigation Committee time plus the lost time and decreased productivity of the injured employee. However, the LWC cost for the investigation committee was only $16 \%$, as opposed to $42 \%$ for the RI case. As one might expect, the total of the lost time and the decreased productivity time attributed to the LWC accident made up the major percentage of the cost (i.e., 63\%).

Inflation escalators were used to convert the 1979 average cost for a nonoccupational injury and the 1986 average cost of a recordable injury to 1990 dollars. The study of nonoccupational-injury costs at ORGDP included a total of 66 cases from one site, while the occupational-injury study included 57 cases from all four plant sites. The results of this conversion are presented in Table 13. 

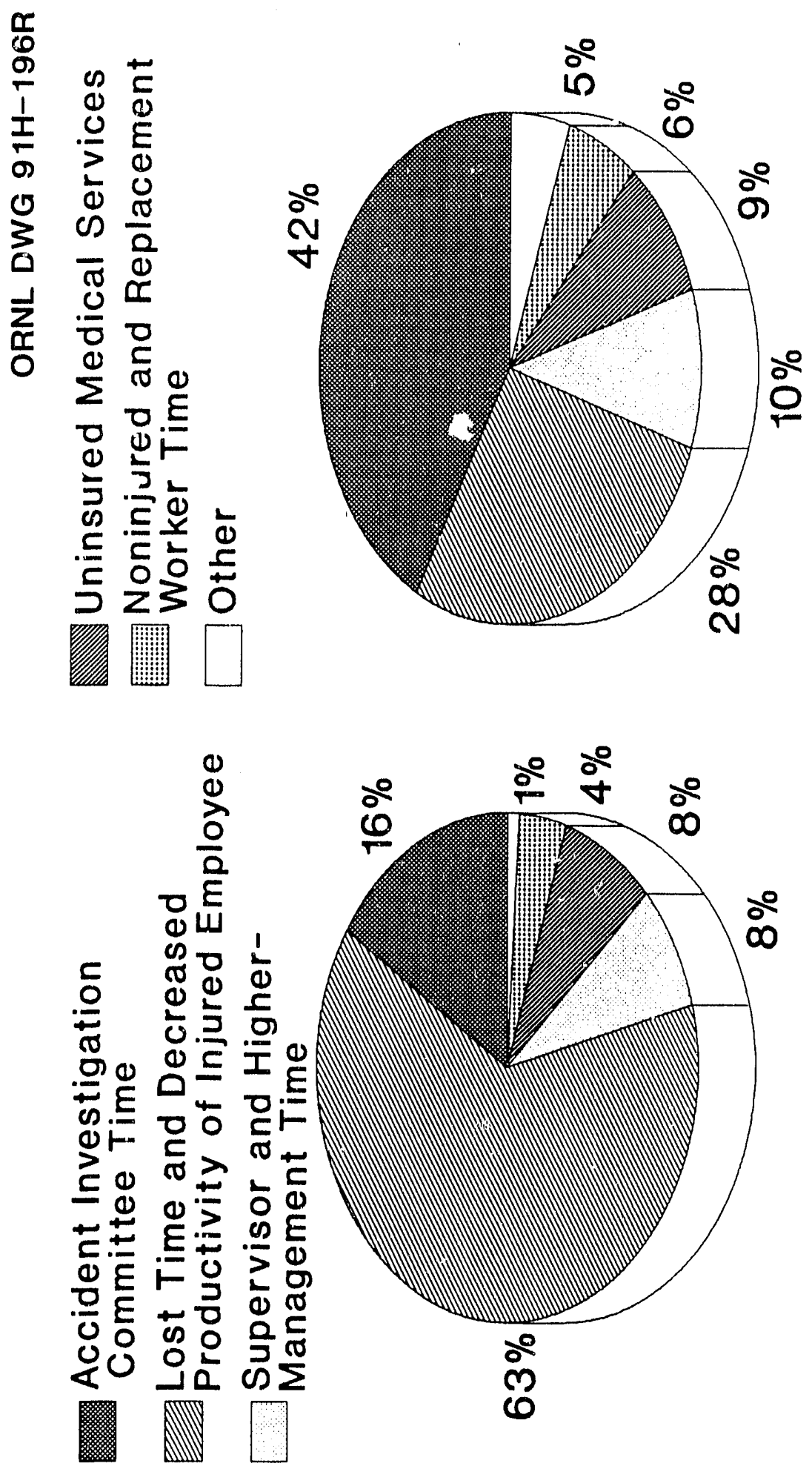

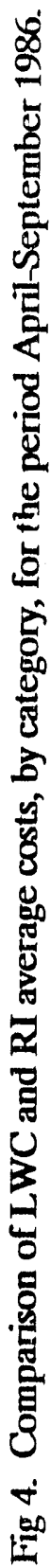


Table 13. Comparison of the average costs of nonoccupational and occupational injuries, in constant dollars

\begin{tabular}{llccc}
\hline & \multicolumn{2}{c}{$\begin{array}{c}\text { Cost of nonoccupational } \\
\text { injury }(\$)\end{array}$} & \multicolumn{2}{c}{$\begin{array}{c}\text { Cost of occupational } \\
\text { injury (\$) }\end{array}$} \\
\cline { 2 - 5 } Payroll designation & $1979^{a}$ & $1990^{b}$ & 1986 & $1990^{b}$ \\
\hline Hourly & 6,449 & 10,139 & 1,927 & 2,079 \\
Weekly & 6,798 & 10,687 & 2,030 & 2,190 \\
Monthly & 3,281 & 5,158 & 1,728 & 1,864 \\
Average & 6,589 & 10,359 & 1,906 & 2,056 \\
\hline
\end{tabular}

${ }^{a}$ Data derived from L. M. Blankenship, Nonoccupational Disabling-Injury Cost Study, SA-457, Union Carbide Corporation, Nuclear Division, Oak Ridge, Tenn., October 1981.

${ }^{b}$ The inflation escalator used in this study was the average annual Consumer Price Index factor. 


\section{DISCUSSION AND CONCLUSIONS}

The purpose of this study was to evaluate the actual recordable injuries for the four facilities at Energy Systems during the last half of fiscal year 1986 and to determine the average cost of a recordable injury. Specifically, the study sought to answer the following questions:

1. What cost figure accurately reflected the expenses incurred for recordable injuries at the four plant sites?

2. What was the average cost of an injury for each site?

3. How did the average cost per injury vary among the three payroll classifications?

The sample consisted of all recordable injuries at the Energy Systems sites during the last six months (April-September) of fiscal year 1986. Approval for the project was obtained from Energy Systems, and a test instrument to collect the detailed elements of cost was designed, reviewed, and approved. The immediate supervisor of each injured employee was asked to prepare a cost data sheet for each incident. Eighty-six percent of the questionnaires were returned. Average costs were calculated, entered into a computer data base, and summarized.

The findings of this study were as follows:

1. There were two major accident categories of the 57 recordable injuries included in this study. Three were lost-workday cases; the remaining 54 were recordable injuries that required medical treatment other than first aid.

2. The total cost for all 57 recordable injuries at the four plant sites was $\$ 108,663$.

3. The average cost of an injury for each site was $\$ 1342$ for ORGDP, $\$ 1782$ for Y-12, $\$ 2822$ for ORNL, and $\$ 2360$ for PGDP. The average cost for all Energy Systems injuries was $\$ 1906$.

4. The following variation was observed in the average cost per occupational injury among the three employee payroll classifications: monthly, \$1728; weekly, \$2030; and hourly, $\$ 1927$.

5. The average nonoccupational disabling-injury cost rate for ORGDP was consistently greater than the average recordable-injury cost rate for Energy Systems; ${ }^{26}$ however, each case showed a similar pattern with regard to the ranking of the average cost per injury among the payroll classifications. The average cost per nonoccupational injury declined in the following order for payroll classifications: weekly, hourly, and monthly. 
In summary, four major conclusions were drawn from the findings of this study:

1. The overall average cost of a recordable injury was between $\$ 1340$ and $\$ 2360$.

2. The average cost of a recordable injury at Energy Systems had a variable cost-per-injury rate.

3. The average cost of a recordable injury at Energy Systems varied according to the site.

4. The average cost of an injury was greater for the weekly payroll employees than for the monthly and hourly employees.

These conclusions confirmed the findings from previous studies. The average cost of an injury is variable, depending on the plant site and the payroll designation. Utilizing the overall average cost per injury of $\$ 1906$, the total cost for all recordable injuries at Energy Systems for 1986 was $\$ 1906 \times 122$, or $\$ 232,532$. 


\section{REFERENCES}

1. N. A. Ashford, Crisis in the Workplace: Occupational Disease and Injury, MIT Press, Cambridge, Mass., 1976, p. 49.

2. J. Ledvinka, Federal Regulation of Personnel and Human Resources Management, Kent Publishing Company, Boston, Mass., 1982, p. 185.

3. M. L. Weidenbaum, Business Government and the Public, Prentice-Hall, Englewood Cliffs, N. J., 1977 , p. 66.

4. Accident Facts 1987 Edition, National Safety Council, Chicago, Ill., 1987, p. 4.

5. Occupational Safety and Health Act of 1970, Pub. L. 91-596, Sect. 8(c)(2), p. 1599 (1970).

6. Martin Marietta Career Opportunities, Martin Marietta Energy Systems, Inc., Oak Ridge, Tenn., 1984, p. 1.

7. A. L. Thygerson, Safety Concepts and Instruction, 2nd ed., Prentice-Hall, Englewood Cliffs, N. J., 1976.

8. J. V. Grimaldi and R. H. Simonds, Safety Management, 3rd ed., Richard D. Irwin, Inc., Homewood, Ill., 1975, p. 395.

9. J. V. Grimaldi and R. H. Simonds, Safety Management, 3rd ed., Richard D. Irwin, Inc., Homewood, Ill., 1975, p. 396.

10. Directory of Terms Used in the Safety Profession, American Society of Safety Engineers, Park Ridge, Ill., 1981, p. 1.

11. F. C. Rinefort, "A New Look at Occupational Safety," The Personnel Administrator 22(9), 30 (1977).

12. F. C. Rinefort, "A New Look at Occupational Safety," The Personnel Administrator 22(9), 32 (1977).

13. N. K. Walters, "Safety Management Accountability Process: An Effective Approach at Du Pont," Professional Safety 28(8), 36 (1983).

14. L. C. Smith, "Training for Total Loss Control," National Safety News 128(6), 53 (1983).

15. R. H. Simonds, The Development and Use of a Method for Estimating the Cost to Producers of Their Industrial Accidents, Northwestern University, Evanston, Ill., 1948, p. 119.

16. R. H. Simonds, The Development and Use of a Method of Estimating the Cost to Producers of Their Industrial Accidents, Northwestern University, Evanston, Ill., p. 177. 
17. J. V. Grimaldi and R. H. Simonds, Safety Management, 3rd ed., Richard D. Irwin, Inc., Homewood, Ill., 1984.

18. J. J. Imre, Uninsured Costs of Work Accidents: Replication and New Applications of Simonds Method, Michigan State University, East Lansing, Mich., 1976, p. 151.

19. L. M. Blankenship, "Nonoccupational Disabling-Injury Costs," Professional Safety 28(8), 28 (1983).

20. L. M. Blankenship, Nonoccupational Disabling-Injury Cost Study, K/DSA-457, Union Carbide Corporation, Nuclear Division, Oak Ridge, Tenn., October 1981.

21. T. Miller, Statistics Department, National Safety Council, Personal Communication, April 9, 1991, p. 29.

22. J. V. Grimaldi and R. H. Simonds, Safety Management, 3rd ed., Richard D. Irwin, Inc., Homewood, Ill., 1974, p. 606. 
APPENDIX A

INVESTIGATOR'S COST DATA SHEET FOR RECORDABLE INJURY 


\section{MARTIN MARIETTA ENERGY SYSTEMS, INC., INVESTIGATOR'S COST LATA SHEET FOR RECORDABLE INJURY APRILS'EPTEMBER 1986}

1. TIME LOST BY INJURED WORKER WHILE BEING PAID BY EMPLOYER (other than Workmen's Compensation payments).

a. Time lost on day of injury for which worker was paid, hours __ minutes.

b. Number of subsequent days' absence for which worker was paid, than Workmen's Compensation payments), hours per day. days (other

c. Number of additional trips for medical attention on employer's time on succeeding days after worker's return to work,

d. Additional lost time by employee, for which she/he was paid by company, hours minutes.

2. DECREASED PRODUCTIVITY OF WORKER AFTER INJURY. If the employee is able to return to work before the injury is completely healed, he/she may not be able to produce at the normal productivity level. While the productivity loss cannot be precisely measured, the experienced supervisor should be able to make a reasonably good estimate of the productivity. This assessment should take into consideration any temporary or permanent medical restriction. (Assume that normal productivity equals $100 \%$.)

a. Total time on light work or at reduced output: days.

(Express to the nearest $0.25-\mathrm{h}$ increment.)

b. Worker's average percentage of normal output during this period,

3. TIME LOST BY EMPLOYEES WHO WERE NOT INJURED. The natural concern of people about accidents (especially friends and co-workers) makes it predictable behavior for workers to discuss the accident and/or assist the injured worker. Because this time lost constitutes a secondary cost associated with the Recordable Injury or Illness (RII), it must be included in the cost estimate. Please list the following information: a.

\begin{tabular}{|l|l|l|l|l|l|}
\hline Employee & Badge Number & $\begin{array}{l}\text { Payroll } \\
\text { Classification } \\
(\mathrm{H} / \mathrm{W} / \mathrm{M})^{*}\end{array}$ & $\begin{array}{c}\text { Amount of Time } \\
(0.25 \text { hour })\end{array}$ & $\begin{array}{l}\text { Pay** } \\
\text { Schedule }\end{array}$ & Shift \\
\hline & & & & & \\
\hline & & & & & \\
\hline
\end{tabular}

${ }^{*} \mathrm{H}=$ hourly; $\mathrm{W}=$ weekly; and $\mathrm{M}=$ monthly.

** Indicate the pay schedule as straight time, one and one-half, or double time. 
b. Number of workers who lost time because they (1) lacked equipment damaged by incident or (2) to aid injured worker

Average amount of time lost per worker, hours minutes.

4. LEARNING PERIOD FOR NEW OR REPLACEMENT WORKER. If the injured worker was temporarily or permanently replaced by one or more employees, the direct wage cost for the learning period must be included in the estimate.

Average percentage of normal output during time, $\%$.

\begin{tabular}{|c|c|c|c|c|c|c|}
\hline Employee & $\begin{array}{l}\text { Badge } \\
\text { Number }\end{array}$ & $\begin{array}{l}\text { New } \\
\text { Replace- } \\
\text { ment }\end{array}$ & $\begin{array}{l}\text { Payroll } \\
\text { Classification } \\
\text { (H/W/M) }\end{array}$ & $\begin{array}{l}\text { Learning } \\
\text { Time Spent } \\
(0.25 \text { hour })\end{array}$ & $\begin{array}{l}\text { Below- } \\
\text { Normal } \\
\text { Output } \\
(0.25 \mathrm{~h})\end{array}$ & $\begin{array}{c}\% \\
\text { Productivity }\end{array}$ \\
\hline & & & & & & \\
\hline & & & & & & \\
\hline & & & & & & \\
\hline & & & & & & \\
\hline & & & & & & \\
\hline
\end{tabular}

5. OVERTIME REQUIRED DUE TO THE RII. If lost production was made up by overtime work, we must determine how much more the work cost than if it had been done on the regular shift. To do this, please list employees paid for overtime below.

\begin{tabular}{|l|l|l|l|l|l|}
\hline Employee & $\begin{array}{l}\text { Payroll } \\
\text { Classification } \\
(\mathrm{H} / \mathrm{W} / \mathrm{M})^{*}\end{array}$ & $\begin{array}{l}\text { Badge } \\
\text { Number }\end{array}$ & $\begin{array}{l}\text { Overtime } \\
(0.25 \text { hour })\end{array}$ & $\begin{array}{l}\text { Pay** } \\
\text { Schedule }\end{array}$ & Shift \\
\hline & & & & & \\
\hline & & & & & \\
\hline & & & & & \\
\hline & & & & & \\
\hline
\end{tabular}

${ }^{*} \mathrm{H}=$ hourly, $\mathrm{W}=$ weekly, and $\mathrm{M}=$ monthly.

**Indicate the pay schedule as one and one-half or double time.

6. TIME REQUIRED BY IMMEDIATE SUPERVISOR OR CLERICAL WORKERS. Since the immediate supervisor must divert a portion of his/her time to the accident/ injury-related matters, this time loss must be considered in estimating the average cost of 
an RII. This could include time spent in accident investigation, supervision of cleanup activities generated as a result of the incident, completion of Accident Investigation Report, or other directly related activities immediately following the event or delayed.

\begin{tabular}{|l|l|l|}
\hline Supervisor & Badge Number & Time Spent ( 0.25 hour $)$ \\
\hline & & \\
\hline
\end{tabular}

\begin{tabular}{|l|l|l|}
\hline Clerical Worker & Badge Number & Time Spent (0.25 hour) \\
\hline & & \\
\hline
\end{tabular}

7. TIME REQUIRED BY HIGHER MANAGEMENT IN CONNECTION WITH THE

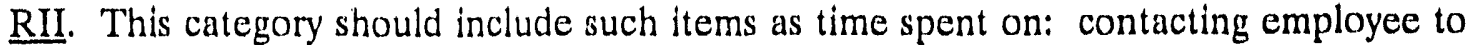
show interest and concern, reviewing Accident Investigation Reports, briefing others about the accident, and meeting to cover the injured worker's job. (Do not include safety or prevention activities or the immediate supervisor's time covered in question 6 above.)

8. WORKMEN'S COMPENSATION. Was Workmen's Compensation filed? Yes No

9. MISCELLANEOUS COSTS. Other costs, not covered above, should be included (e.g., cost of renting replacement equipment; long-distance telephone calls related to accidents; cost of excessive materials to train new employee; demurrage). Explain fully. 
APPENDIX B

ACCIDENT INVESTIGATION REPORT 


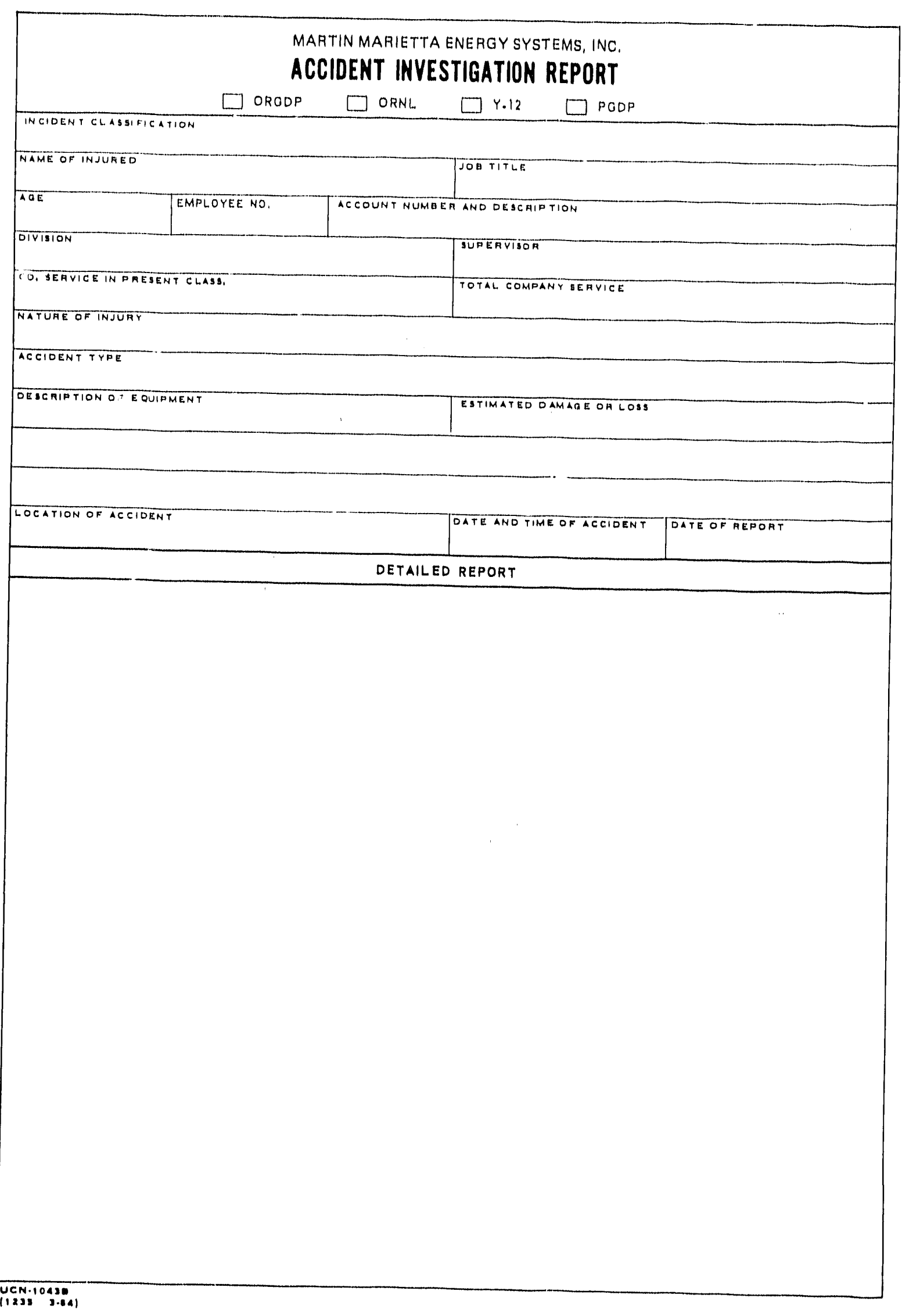




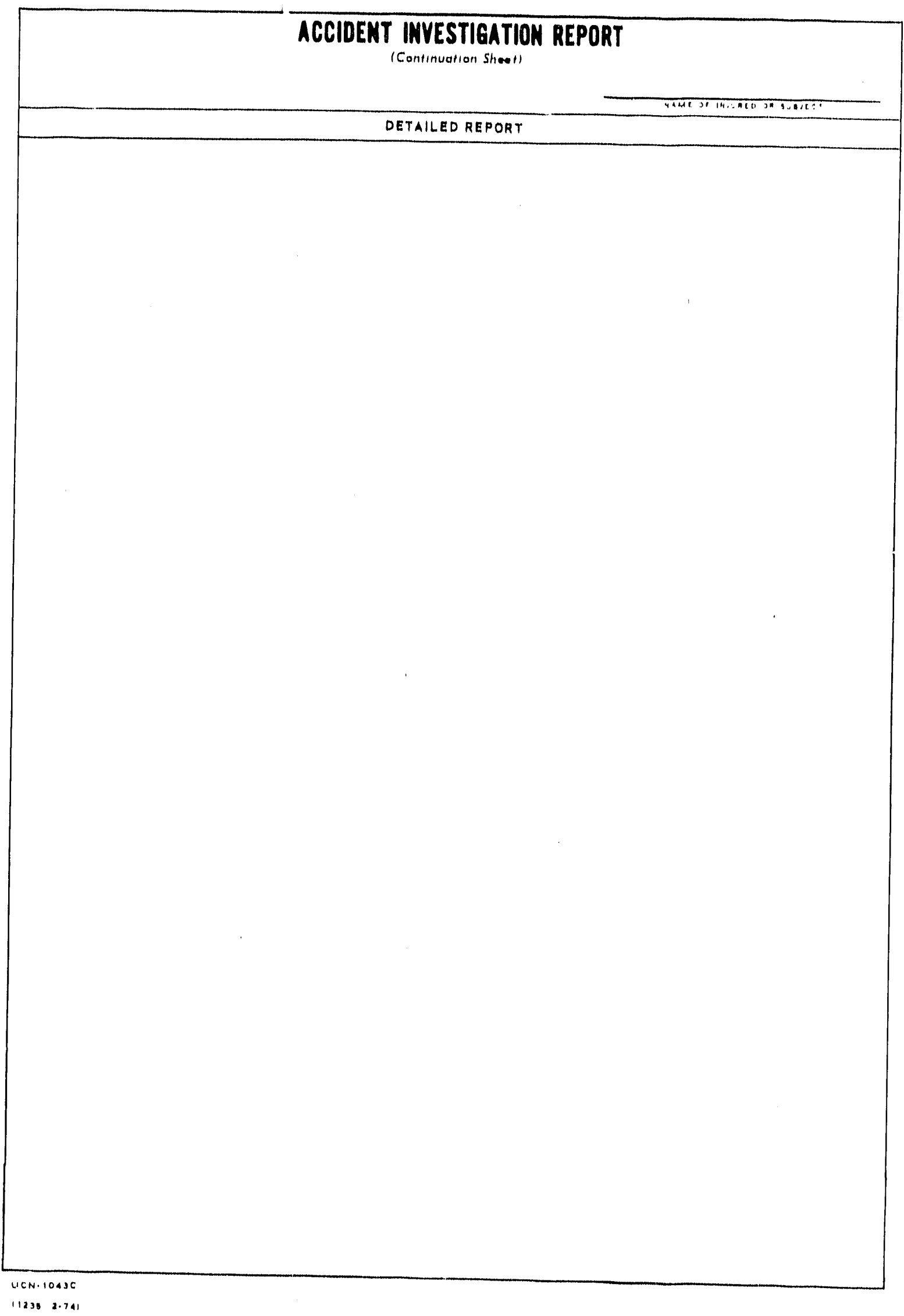




\section{INTERNAL DISTRIBUTION}

1. J. S. Brown

2. T. R. Butz

3. S. D. Clinton

4. W. Fulkerson

5. R. K. Genung

6. R. W. Glass

7. P. A. Gourieux

8. D. W. Holladay

9-59. E. K. Johnson

60. M. K. Knazovich

61. D. Milan

62. J. D. Miller

63. W. S. Nichols
64. J. H. Parker

65. T. H. Row

66. D. P. Stevens

67. M. G. Stewart

68. J. H. Swanks

69. L. O. Wyatt

70. G. C. Young

71. Central Research Library

72. Document Reference Section

73. Laboratory Records

74. Laboratory Records, RC

75. ORNL Patent Section

\section{EXTERNAL DISTRIBUTION}

76. Office of Assistant Manager, Energy Research and Development, DOE-OR, P.O. Box 2001, Oak Ridge, TN 37831-8600

77-86. Office of Scientific and Technical Information, P.O. Box 62, Oak Ridge, TN 37831 
